\title{
Bush Allowance and Alienation: A Challenge to African Leadership and Development in Kaine Agary's Yellow-Yellow
}

\author{
Ngozi Ezenwa-Ohaeto \& Toochukwu John Ezeugo \\ http://dx.doi./org/10.4314/ujah.v20i3.3
}

\begin{abstract}
African countries have experienced various forms of alienation both from natural occurrences and human forces. Environmental hazards have displaced some people from their parents and their ancestral homes. On the other hand, exploitation, privatization and uneven distribution of natural resources of the people by few privileged individuals, especially the politicians, have also alienated the people from their environment. Attempt to agitate or confront these factors of displacement and alienation often leads to a compromise and reliance on meager allocation of bush allowance which serves as compensation to the people. It is no doubt that this denial of collective participation of people in decision, especially as it concerns their welfare and natural minerals, has contributed to poor leadership and under development of Africa amidst her abundant resources. The alienation of people from decision has become some sort of abortion of dreams and suppression/ obliteration of ingenuity capable of transformation and development. This study is a qualitative research which seeks to textually explore the concept of bush allowance and alienation in Agary's Yellow-Yellow in order to examine the extent they affect leadership quality and development in Africa, especially in Niger-delta of Nigeria. To do this the principle of Eco-centrism and the theory of Empowerment are used as analytical models as well as theoretical framework. Findings revealed that exploitation of natural minerals by those in
\end{abstract}


Ezenwa-Ohaeto \& Ezeugo: Bush Allowance and Alienation: A Challenge to African Leadership and Development in Kaine Agary's Yellow-Yellow

authority has more adverse effects on the people than the environmental forces. The alienation of people from the decision making process creates imbalance and violence in society which deter development especially in Africa. This study also shows that over dependence in bush allowance affects self development and empowerment. The study therefore concludes that the development of a people is in their hands.

Keywords: Bush allowance, leadership, alienation, development, Yellow-Yellow

\section{Introduction}

African countries over the years have been referred and addressed as either developing countries or underdeveloped countries. This has remained a recurring surname in Africa amidst her abundant human and natural resources. However, the development of Africa and her leadership have been bedeviled by a lot of factors ranging from natural hardship to human corrupt practices. One of the major problems faced by Africa in general and Nigeria in particular is alienation. Alienation is the displacement or dissociation of one from one's people or environment leading to lose of identity. This displacement could be natural (environmental hazards and despoliation) or humanly constructed exploitation and isolation that manifest itself in various ways: psychological, emotional, physical, sexual, and financially. Irrespective of the way it comes, it affects leadership, and retards development of a society. This is because "alienation according to Saleem is the basic form of rootlessness" (67).

In some parts of Nigeria, people have been estranged from their ancestral homes, and isolated from their land by those that belong to the 'powers that be'. They have also been denied of 
taking part in the decision making process of their own environment. According to Kaufman, "to claim that a person is alienated, is to claim that his relation to something else has certain features which result in avoidable discontent or loss of satisfaction" (13). Often times, alienation is created for personal advantages by few individuals that occupy political positions and other helm of leadership. The masses however, in attempt to question and fight this gruesome deprivation of one's happiness and existence resolve to violence, and other times accept a compromise with the offer of a temporary incentive dubbed 'bush allowance' in this paper.

On the other hand, 'bush allowance' is a special allowance paid to soldiers on border duty as incentive for them to accept to remain in such volatile area. It could also liken to the additional money given to teachers who accept to be posted in the most remote and rural areas where there are no basic amenities as found in the city. Ironically, in some African countries these workers have created for themselves additional way of happiness in their work place. Some of the teachers and soldiers in rural areas sleep with pupils and sexually exploit young girls in the rural areas as their reward for working in such places. Be that as it may, 'bush allowance' serves as bait that lures and endears one to an undesired situation. It is an instrument that denies self expression, and lubricates alienation by softening the emotional and psychological effects of deprivation. However, this study will see bush allowance in two dimensions: compensation for the citizens from government and the oil companies and, compensation (exploitation) created by workers and other expatriate in Niger-Delta as captured in Agary's Yellow-Yellow.

Hence as long as the bush allowance keeps coming, the beneficiaries keep working to favour of their pay masters. On the 
contrary, any day it fails to come and, as at when due, the beneficiaries revolute vehemently, and remember their real state of isolation. Their actions often destroy already existing developmental strides and everything around them. This is so, because bush allowance makes a temporary contribution to their development. Relative to alienation and bush allowance in post colonial modern African literature are issues of marginalization and exploitation which the works of Tess Onwueme, Esiaba Irobi and so many others writers captured.

Although the psychological and physical effects of alienation and exploitations have been studied by other scholars but its influence and the place of bush allowance vis-a-vis human and environment development have been given little or no attention. This study therefore examines bush allowance and alienation as the problem of leadership in resource management and development of Africa in Kaine Agary's Yellow-Yellow. It seeks to investigate how the displacement caused by human and natural factors deters sustainable human and environmental development in African especially in Niger Delta region of Nigeria where the novel is set. The principle of eco-centrism and the theory of empowerment are employed in analyzing the novel to find out how the environment bastardized human existence, and how human beings consciously hinder the development of the society. This study is not offering a Marxist orientation but rather provides a different dimension in evaluating leadership and developmental challenges in Africa, Nigeria in specific.

\section{Bush Allowance and Alienation in Leadership and Development}

The influence of colonialism and its aftermath have almost formed the major canonical features of post colonial African literature. 
This is because it has appeared to become a protracted phenomenon that Africa and her leadership conduct their affairs in the ways of their colonial master even after decades of colonialism. Regrettable this principle that African leaders operate on are alien to them and their cultural existence; and were purposeful employed by the colonial masters for exploitation and selfish interest, hence not appropriate in African society today. The participation and opinions of Africans in colonial governance and administration were inconsequential to them because they will not in any way boost their desired goals. The use of alienation and deceptive compensation method by African leaders indicate a show of poor leadership quality and eroded identity. Buttressing this, Eegunlusi has this to say:

Though, Africans survived colonialism, the ushering in of neo-colonialism by post-colonialism made African identity so complex to deal with. Currently, the crises of the African continent have to do with the moral and communitarian structure on which this identity rests. This introduces two complex problems: first, the erosion of our heritage of moral discipline, dignity, diligence, faithfulness, honesty and sound integrity; second, unbearable level of conflicts emanating from intolerance due to unguarded acceptance of alien western doctrines that constitute threats to human and material resources on the African continent (2).

These attitude and alienation principle are very much capable of incapacitating developmental efforts in African. In fact, they are capable of making Africa like in the words of Hobbes "in a state and nature in which human life is "solitary, poor, nasty, brutish, and short" (58). It is therefore no doubt that a meaningful and 
constructive development of the continent is hampered and her people are rated among the poorest in the world.

To further examine alienation and its consequential dispossession, it is worthwhile to understand various nuances of the word alienation. 'Alienation' is derived from the Latin word 'Alienato', a noun which receives meaning from the verb alienate' means to make a thing for others, or to avoid. Alienation is "the state of being alienated or estranged from something or somebody; it is a condition of the mind" (Dictionary of Literary Terms). Although, alienation affects the mind, and could be conditioned by the state of the mind but one could be physically estranged from his home or other privileges and rights that belong to him or her. This also embodies the meaning of alienation that this study investigates.

In Niger- Delta region of Nigeria, it has been noted that alienation is the root cause of militancy (Joab-Peterside 30). The region which has the greatest sources of the nation's wealth that has formed the mainstay of Nigeria's economy (oil) feel estranged from their environment, and source of livelihood by oil exploitation and exploration by the government and its allies without any consideration. Hence they became restive and refute the forces of their dislodgement. This Frederick summed as the alienation from natural resources and species being endangered (5). Both lives and development of the region are endangered. Although oil companies and industries are heavily situated in the region which ought to enhance rapid development of the area but ironically, the rate of poverty were on increase in the face of riches. It appears that these industries were mainly situated to milk the people's resource.

Little wonder, the literature on the Niger Delta agrees that the oil industry has not promoted the development of the region; 
rather, it has undermined the area's development. Aaron for example has noted that:

Oil has meant for the indigenes of the Niger Delta, wrenching poverty...Peoples Rights have come under severe assault by the ecologically unfriendly practices of oil Transnational Corporations (TNC's). In addition, State laws and policies as they relate to petroleum resources, expropriate the indigenous peoples of the Niger Delta of their 'right' to their natural resources ... (194).

Due to the non inclusiveness of the people in the plan and management of their environment, the success of the oil economy has not promoted their own capacities. According to Brown, "It has also not promoted their own self-reliance and the social engine of the society... the pace of development has left them". The people are pushed to militancy and attack to reclaim the control of their own environment. The question however, is who stands to lose? This notwithstanding, Ibaba notes that oil based environmental degradation and ethnic based political domination have combined efforts to alienate the people from the use of their natural resources for their own development (15).

Naanen and other researchers see alienation caused by the environmental consequence of the oil industry to have been exacerbated by ethnic based political domination and the failures of accountability and transparency in government. Rather government working on the modality to adjust their leadership quality and make legal provision where they could include the people into the management processes of their own property, they resolve into 'bush allowance' (compensation).

Bush allowance is interchangeable used as 'hardship allowance'. According to Farlex it is an additional pay that an 
expatriate employee may receive for living and working in a potentially dangerous area; additional vacation time and other benefits are sometimes included (web). These expatriate sometimes lord themselves over the people of their community to take undue advantage of them and hide under the disguise of assisting them, as well maintaing their own happiness. This bush allowance method however, has only created another intractable problem in Niger-Delta region. Aghalino traced the intractable problem over compensation for oil spill damage in Nigeria to colonial origin of the oil industry and skewed template of laws which disregard the interest of victims of the negative externalities from the oil industry; the compensation paid by oil industry does not reflect market price and fall short of international standard (190).

The problem in this region and African generally is beyond payment of bush allowance. This is so because, the influence of the oil exploitation is not only on goods and service but on the lives of people which are not tractable by mere compensation. In order to effectively manage conflict in Niger Delta, Okoh proposed collaborative problem solving method. By this approach, participants, especially the voiceless are given equal chance to express their grievances, views, and have input to the final decision (92). This improves the understanding of policy makers of the issue at stake and boosts the community's trust in government and its intentions.

Kaine Agary's Yellow-Yellow has attracted a lot of criticisms and acceptance from both scholars and other individuals. Orie opined that Yellow-Yellow "is a novel of adventure, of agitation over the natural and human-manufactured harm to the Niger Delta lands and her people, in the guise of oil exploitation" (196). Although, Orie captures the agitation against alienation 
created by nature and human but its influence in leadership quality and the development of the society was not noted.

Orie's view tends to agree with Onukaogu and Onyerionwu's consideration of the causes of militancy, prostitution and other kinds of moral shortcomings in the society. In their words:

"In Yellow Yellow, Agary is also interested in the calamity of the destruction of the human resources base in the Niger Delta. This phenomenon had given rise to militancy, prostitution and other kinds of moral shortcomings in the area" (127).

The idea of how alienation and compensation (bush allowance) has aborted the potentials and dreams of people capable of fine-tuning good leadership and contributing to the development of the country, Nigeria remains an issues of concern found in the novel, Yellow-Yellow which many scholars have not explored.

\section{Methodology and Theoretical Framework}

Bush allowance and alienation in African, Nigeria in particular, and how it bedevil leadership and development will be textually explored in this paper using Kaine Agary's Yellow-Yellow as the primary source of material, while the library and internet forms the secondary source of information in this study. Ecocriticism and Empowerment theories are used as the model of the theoretical framework.

The term ecocriticism was first coined by William Rueckert in his critical writing "Literature and Ecology: An Experiment in Ecocriticism" in 1978.The word 'eco' comes from the Greek root word 'oikos' which etymologically means household or earth and 'logy' from 'logos' means logical discourse. Put together means 
criticism of the house (the environment) as represented in literature. Ecocriticism according to Mishra gets its inspiration in literature from the three major American writers whose works celebrate nature as a life force, and the wilderness as manifested in America. They are Ralph Waldo Emerson (1803-1882), Margaret Fuller (1810- 1850), and Henry David Thoreau (1817-1862). According to Rueckert, ecocriticism applies to ecology or ecological principles into the study of literature. Lawrence Buell defines ecocriticism "as a study of the relationship between literature and the environment conducted in a spirit of commitment to environmentalist's praxis" (The Environmental Imagination, 430). In Yellow- Yellow, Agary pictures and criticizes the ecological impacts in the lives of the people of Niger-Delta. Hence it is important to this study. Again, ecocriticism with its ethical stand and commitment to the natural world makes the connection between the human and the non-human world realistic. It seeks to locate the vestiges of nature in cities and exposes crimes of ecoinjustice against society's marginal section. The Ecocritic interprets nature writing texts.

Empowerment theory in line with Zimmerman's view is also adopted for this study. Empowerment is seen as intentional, ongoing process centered in the local community, involving mutual respect, critical reflection, caring and group participation through which people lacking an equal share of valued resources gain greater access and control over those resources (Cornell Empowerment Group 2). The theory is both a value orientation for working in community and theoretical model for understanding the process and consequences of efforts to exert control and influence over decisions that affects one's life, organizational functioning and quality of community life (Zimmerman 43). In Yellow-Yellow, the lost their identity and leadership gripe because of lack of 
appropriate empowerment structure. This theory provides the model and helps advance the construct better life beyond a transiting vogue and political manipulation.

\section{Analysis of Bush Allowance and Alienation in Kaine Agary's Yellow-Yellow}

The idea of displacing people from their homes, their source of livelihood is comprehensively captured in the novel Yellow-Yellow. The author, Kaine Agary attempted to expose the problems of such alienation from both ecological and human factors; how it has bedeviled human and environmental development was also captured in the text. Hardship allowance given to the people for the challenges they face from the environmental exploration and displacement clothed with the intent of milking them and their environment were also pictured in the novel. These we shall analyse here in this paper.

\section{Bush Allowance}

Incentive given to the Niger-Delta region of Nigeria by oil companies and government in form of compensation hindered development and merely generated more troubles and controversy among the people. This is captured in the novel:

I joined them to find out what had happened. It turned out some of them had also lost their farmland that day. They were marching to the Amananaowei's house to report the matter and demand that he take it up with the oil company. Some were crying; others were talking about compensation (4).

The allowance became a weapon for controlling the behaviour of the restive youths; the agitation of displaced men and women. 

African Leadership and Development in Kaine Agary's Yellow-Yellow

They used it to take charge of the socio-economic live of the people and their environment; such that, any attempt by the people to contravene may result in not receiving the compensation. When they are paid, more exploration and displacement will be witnessed:

The community took the matter up with the oil company that owned the pipes, but they said they suspected sabotage by the youths and were not going to pay compensation for all the destruction that the burst pipes had caused (4)

The people were made to merely see the allowance they receive as their entitlement and what they live to gain. They become conscious only on the compensation and nothing about the mineral resources which ought to be their basic source of living. They rather depended heavily on bush allowance for survival that it became a matter of life or death:

Young boys threatened to rough up the Amananaowei and his elders because rumours, probably true, had reached their ears that the Amananaowei and his elders had received monetary compensation, meant for the village, from the oil company and shared it amongst themselves. These images darkened the canvas of the village life (40).

The energy and ingenuity of these people were misappropriated as they would have been better channeled towards collective development of their community and leadership. Having mortgaged their ideas and reasoning in the meager allowance from the oil, they never thought of diplomatic and proactive measure of manning their own economic administration, rather they resolve in destruction of pipelines in order to get share of their own property. Some of the compensation programmes in disguise of 
empowerment and skill acquisition packaged for the people by the government were mere caricature and instrument for sustaining alienation. This is seen in the text from the confession below:

I imagine that I could learn a skill like sewing through one of the skill acquisition programmes organized by the government agency set up to address the development needs of the Niger Delta. None of theprogrammes had reached my village since the agency was formed (43).

The oil companies presented some enticing incentives to those who are educated whom they see as the major threat in their profit making business. They were given employment in their companies irrespective of their specializations and areas of study. This Agary carefully captured:

The oil companies held the pot of gold for all graduates. Most of them provided health care services to their employees through their own hospitals, so doctors were on their payroll. It seemed the oil companies could find a place for every degree-lawyers, administrators, geographers, and engineers were required; all other disciplines fed the nontechnical units, including community relations (33).

Another form of bush allowance that manifested in the novel was sexual exploitation and monetary gifts from the white expatriates. Young girls in a bid to survive and belong to the class of 'city ladies' accepted to go along with the oil company workers especially the White whom they believe could pay more compensation to them than the ones they received through their village heads and leaders. This Zilayefa noted that her mother was a victim of, and Zilayefa herself became a product of same, and a reward of Africa, 'African profit': 

African Leadership and Development in Kaine Agary's Yellow-Yellow

There could have been something they offered besides money, that thing that my mother had fallen for. It was that thing I had been looking to key in to. I had wanted to understand what it was besides money that made beautiful twenty -year-old girls look at their short, fat, ugly fiftyeight-year-old white husbands with so much affection. Maybe then I could understand better or with less anger why there were more and more of my kind - "African Profits", "born troways", "ashawo-pickins", "fatherunknowns," (171).

This survival strategy by the people especially the young girls became a source of fun and happiness to them, although not their desired type of life but their orientations have been influenced by the 'bush allowance' relationship. The development of the people therefore becomes very difficult in the face of their situation.

\section{Alienation in Yellow- Yellow}

In the novel, Yellow-Yellow, there are two dimensions of alienation; alienation of people from their homes and environment by nature, and alienation from human beings. The thing which nature allowed for generations to sustain the people and their family sudden becomes against them just like flood suddenly pushes people away from their family:

Farming and fishing, the occupations that had sustained my mother, her mother, and her mother's mother no longer provide gain... (31)

Due to oil spillage in Niger Delta, the people were made to pass a lot of pains and troubles as their agricultural source of livelihood which was common for all could no longer accommodate them. 
The sources of food and water were destroyed, and contaminated. To heighten this, they were also excluded from taking part in the benefits that come from the oil, and in decision making of their own property; the people were excluded from their own wealth, "and na our money o! na our oil money" (38). This has introduced a high level of poverty on them such that the people begin to decry their ugly condition. Agary through her character describes the lamentation of the people:

How many more times could I bear the pain like a hundred razor blade slashing my private part because the river water that washed it was the same water that received the waste rejected by my body in its attempt to cleanse itself? The water that flowed with streaks of blue, purple and red, as drops of oil escaped from the pipelines that moved the wealth from beneath my land and into the pockets of the selected few who ruled Nigeria was the same water I drank (34).

Examining the challenge of leadership as the major slayer of African society, Nigeria in particular, Kiane Agary focused on the activities of the multinational oil companies and the government in Niger Delta who kept on exploring and making gains from the people's resource without considering their pains and suffering. They were only made to watch but not to touch. They become what Mortimer referred to as "inner lamp not outer lamp"; they have wealth but cannot show anything for it. The people were opened to all sorts of decision and unpalatable means to survive. Some went into prostitution and other 'bush survival' activities. Zilayefa resolves: 
I was open to all sorts of things. The only option I was unwilling to consider, that tormented my quiet moments the most, was to remain in my village (39).

The alienation of this people and their decision to carve out a better living condition for themselves often produced another form of displacement, abandonment and pains. For example the character Bibi, Zilayefa's mother is described as one who had her early life planned with high dreams of becoming great; made effort to leave village to urban area where she can see light to her dreams. Unfortunately her dreams were aborted by her meeting with her Greek sailor boyfriend who got her pregnant and abandoned her. This orientation influenced her parental relationship and Zilayefa's upbringing: even though I grew up in the village, my mother had been very protective of me (27). Other decisions of survival like mutiny had even led to death and destruction of many. The case of Ken Saro- Wiwa is an example

\section{Conclusion}

The development of every nation must manifest in every aspect of the nation and in the overall well being of the citizens. It is a process that puts everyone into consideration and as well carries the people along in the share of ideas. The assessment of a quality leadership is in how best the people are empowered and the amount of happiness that they display daily. The people cannot be separated from their environment and resource in pursuit of good leadership and development. Alienation can only create more challenges to the society. It will increase the high rate of crimes and social vices endemic to development and its sustainability. Compensation of people in form of bush allowance is a disguise and bride to insubordinate and 'milk ones breast' unpardonable. It 
is temporary and cannot take the place of inclusion and empowerment. It does not solve the problem of leadership and development, rather it creates more problems

This paper urges the people to stand on their ground in unity and not in divergent decisions of survival to challenge bad governance and unnecessary exploitations. This could be done in various spheres of lives. Let the same thing be advocated collectively at different institutions of the country. The more people are alienated the more proliferation of terrorism and provoking groups that will breed destruction in the society. For any meaningful achievement and development people should be empowered and allowed to manage their own resource

\author{
Ngozi Ezenwa-Ohaeto (PhD) \\ Department of English Language \& Literature \\ Nnamdi Azikiwe University, Awka \\ nezenwaohaeto@gmail.com \\ $\&$ \\ Toochukwu John Ezeugo \\ Department of English Language \& Literature \\ Nnamdi Azikiwe University, Awka \\ toochukwuezeugo@gmail.com
}

\title{
Works Cited
}

Aghalino, S.O. "Issues and Trend in the Payment of Compensation in the Oil industry in Nigeria, 1969-1997". Akwa Ibom Journal of History and International Studies. 12.11(2005): 86-208

Anikulop, Jahman. "Entry note to Yellow-Yellow (blurb), YellowYellow". Lagos: Dtalkshop, 
Ezenwa-Ohaeto \& Ezeugo: Bush Allowance and Alienation: A Challenge to African Leadership and Development in Kaine Agary's Yellow-Yellow

Brown, Bobo. "External Relations Manager of the Shell Petroleum Department Company (SPDC) of Nigeria". Environmental Watch 15 July, 2007

Buell, Lawrence. The Environmental Imagination: Thoreau, Nature Writing and the Formation of American Culture. Cambridge, London, England: Harvard University Press, 1995

Cornell Empowerment Group. "Empowerment and Family Support" Networking Bulletin, 1(1989):1-23.

Coupe, Laurence. The Green Studies Reader: From Romanticism to Ecocriticism. USA: Routledge, 2000

Eegulusi, Tayo Raymond. "Mental Alienation and African Identity. Exploring Historical Perspectives in Response to the Crises of African Societies". Open Journal of Philosophy 7(2017):1-24

Farlex, Free Finacial Dictionary, 2012 web 30/09/2019

Fredeerick, A.O. "A Theoretical Consideration of the Niger Delta Crisis. Whose Solution? the People or the Government's". Paper Presented at International Conference on the Nigerian State, Oil Industry and the Niger Delta, Yenagoa, Bayelsa, March 11-13, 2008

Hobbes, T. Ebook of Leviathan. Web 30/09/2019

Ibaba, S. Ibaba. "Alienation and Militancy in the Niger Delta: Hostage Taking and the Dilemma of the Nigerian State". African Network for Environment and Economic Justice (ANEEJ) 2004.

Ikheba, R. "Agary's Yellow-Yellow: A Critical Review".

Retrieved Nov.12, 2013 from

Joab-Peterside, S. "On the Militarisation of Nigeria's Niger-Delta: The Genesis of Ethnic Militia in River State". African Conflict Profile 1.2 (2005): 30-59 
Kaufman, Arnold. "On Alienation" in Richrd Schacht's Alienation.

New York: Double Lay and Company Inc., 1970

Mishra, Sandip Kumar. " Ecocriticism: A Study of Environmental Issues in Literature" BRICS Journal of Educational Research, 6.4 (2016)168-170.

Mortimer, M. Journeys through the French African Novel. London: James Ceny Ltd,1990

Naanen, Ben. "Oil Producing Minorities and the Restructuring of Nigerian Federalism". Journal of Common Wealth and Comparative Politics 33.1 (1995): 46-78.

Okoh, R. N. "Conflict Management in the Niger Delta Region of Nigeria: a Participatory Approach". African Journal on Conflict Resolution 5.1(2007):91-114.

Onukaogu, R. and Onyerionwu, P. From Boom to Doom: Protest and Conflict Resolution in the Literature of Niger Delta (ed) Chinyere Nwahunanya, 2011.

Orie, D. "Wreckless in the Light of Freud: The Unconscious and Conformity in a Social Setting." Web 30/09/2019

Saleem, Abdul. "Theme of Alienation in Modern Literature". European Journal of English Language and Literature Studies 2.3 (2014): 67-76 Web. 30/09/2019

Zimmerman, Marc. A. "Empowerment Theory: Psychological, Organisational and Community Level of Analysis". Handbook of Community Psychology (eds) Julian Rappaport and Edward Seideman. New York: Kluwer Academic/ Plenum Publishers, 2000 